\title{
Excitatory Synaptic Transmission in the Inner Retina: Paired Recordings of Bipolar Cells and Neurons of the Ganglion Cell Layer
}

\author{
Ko Matsui, Nobutake Hosoi, and Masao Tachibana \\ Department of Psychology, Graduate School of Humanities and Sociology, The University of Tokyo, \\ Tokyo 113-0033, Japan
}

Properties of glutamatergic synaptic transmission were investigated by simultaneously voltage-clamping a pair of connected bipolar cells and cells in the ganglion cell layer (GLCs) in the newt retinal slice preparation. Activation of the $\mathrm{Ca}^{2+}$ current in a single bipolar cell was essential for evoking the glutamatergic postsynaptic current in the GLC. Depolarization for as short as $15 \mathrm{msec}$ activated both NMDA and non-NMDA receptors. On the other hand, analysis of the spontaneous glutamatergic synaptic currents of GLCs revealed that these currents consisted of mainly non-NMDA receptor activation with little contribution from NMDA receptors. This suggests that non-NMDA receptors of GLCs are clustered in postsynaptic membrane regions immediately beneath the release sites of bipolar cells and that NMDA receptors have lower accessibility to the re- leased transmitter than non-NMDA receptors. Glutamate that is spilled over from the release sites may activate the NMDA receptors. When a prolonged depolarizing pulse was applied to a bipolar cell, the response induced by non-NMDA receptors was limited greatly by their fast desensitization, whereas NMDA receptors were able to produce a maintained response. The relationship between the pulse duration applied to the bipolar cell and the integrated charge of the response evoked in the GLC was almost linear. Therefore, we propose that both nonNMDA and NMDA receptors cooperate to transfer the graded photoresponses of bipolar cells proportionally to GLCs.

Key words: retina; synaptic transmission; glutamate; nonNMDA receptor; NMDA receptor; EPSC; spontaneous EPSC; bipolar cell; ganglion cell; desensitization; spill-over
Bipolar cells relay visual information from photoreceptors to ganglion cells in the vertebrate retina. Bipolar cells convey information with graded potentials, whereas ganglion cells are the first neurons in the visual pathway capable of firing action potentials (Werblin and Dowling, 1969). It is interesting to know how the characteristics of the synaptic transfer from bipolar cells to ganglion cells differ from those between spiking neurons in the CNS.

Bipolar cells release an excitatory amino acid, probably glutamate, as their neurotransmitter (Slaughter and Miller, 1983; Tachibana and Okada, 1991). Ganglion cells possess two major subtypes of ionotropic glutamate receptors, i.e., non-NMDA receptors and NMDA receptors (Aizenman et al., 1988; Gottesman and Miller, 1992; Cohen et al., 1994). However, there is disagreement concerning the role of NMDA receptors; a major contribution to the ganglion cell photoresponse was suggested by Mittman et al. (1990), but not by Coleman and Miller (1988). Taylor et al. (1995) suggested that non-NMDA receptors and NMDA receptors were segregated predominantly on the proximal and distal dendrites of ganglion cells, respectively.

Most of the previous reports examined photoresponses of ganglion cells to analyze the characteristics of synaptic transmission in the inner plexiform layer (Wunk and Werblin, 1979; Coleman and Miller, 1988; Mittman et al., 1990; Hensley et al., 1993).

Received Feb. 19, 1998; revised March 30, 1998; accepted April 1, 1998.

This work was supported by Grants-in-Aid 07458218 and 09480238 for Scientific Research from The Ministry of Education, Science, Sports, and Culture (to M.T.). We thank Laurence Pinto for critically reading this manuscript. We also thank Takeshi Sakaba and Hiroshi Ishikane for discussions and comments.

Correspondence should be addressed to Dr. Masao Tachibana, Department of Psychology, Graduate School of Humanities and Sociology, The University of Tokyo, 7-3-1 Hongo, Bunkyo-ku, Tokyo 113-0033, Japan.

Copyright (C) 1998 Society for Neuroscience $\quad 0270-6474 / 98 / 184500-11 \$ 05.00 / 0$
However, even when inhibitory pathways are blocked pharmacologically, light stimulation evokes responses in ganglion cells through two stages of synaptic transmission: from photoreceptors to bipolar cells in the outer plexiform layer and from bipolar cells to ganglion cells in the inner plexiform layer. Because photoreceptors also use glutamate as their neurotransmitter (Miller and Schwartz, 1983), glutamate agonists and antagonists applied to the retina would affect synaptic transmission in both the outer and inner plexiform layers. Furthermore, because multiple bipolar cells are connected with a ganglion cell, it is difficult to evaluate pharmacologically the possibility that NMDA receptors and non-NMDA receptors of the ganglion cell are activated by two distinct groups of bipolar cells.

Methods such as the transretinal electrical stimulation (Toyoda and Fujimoto, 1984) and the local application of high potassium (Lukasiewicz and Werblin, 1994), kainate (Maguire et al., 1989), or high osmolarity solution (Yu and Miller, 1995) have been developed to excite bipolar cells directly. However, because bipolar cells are nonspiking neurons, these methods inevitably activate multiple bipolar cells variably.

In the present study the dual whole-cell voltage-clamp method was applied to newt retinal slice preparation to avoid these problems. A single bipolar cell was depolarized, and the resulting EPSC was recorded from a cell in the ganglion cell layer (GLC). We examined whether both non-NMDA receptors and NMDA receptors mediate excitatory synaptic transmission from bipolar cells to GLCs and how these receptors are distributed over the dendrites of GLCs. Furthermore, the relationship between the duration of bipolar cell depolarization and the EPSC was examined to identify the time course of activation of these receptors.

Part of the present work has been presented elsewhere in abstract form (Matsui and Tachibana, 1997). 


\section{MATERIALS AND METHODS}

Retinal slice preparation. The slice preparation was made by following the method described by Werblin (1978) and Wu (1987). Adult newts (Cynops pyrrhogaster), 7-12 cm in body length, were kept at room temperature under a normal day-night cycle of lighting. Animals were dark-adapted for at least $20 \mathrm{~min}$ and cooled in ice for $5 \mathrm{~min}$ before decapitation and pithing. The eyes were enucleated, and the anterior chamber of the eye was opened to remove the iris, lens, and vitreous humor under room light. A piece of filter paper (type GS, pore size 0.22 $\mu \mathrm{m}$; Millipore, Bedford, MA) was placed on top of the eyecup, and the sclera and the pigment epithelium were removed, leaving the retina attached to the filter paper. The filter paper and the retina were sliced into $190 \mu \mathrm{m}$ sections with a razor blade. Slices were transferred to the recording chamber and aligned under a dissecting microscope so that all layers of the retina could be observed. Then the slices were held down by fine nylon threads fastened on a platinum horseshoe (Edwards et al., 1989). These procedures were done within 20 min after decapitation.

Then the recording chamber was placed in a light-tight Faraday cage and mounted onto the stage of a fixed-stage microscope equipped with infrared differential interference contrast optics (Standard, Zeiss, Germany). All subsequent manipulations were performed in a dark room. The retinal slice and recording pipettes were illuminated with an infrared light and monitored on a CRT display connected to a video camera sensitive to the infrared light (C2400-07ER, Hamamatsu Photonics, Hamamatsu, Japan). To photostimulate the retinal slice, we applied a white light through the condenser lens of the microscope. Light-evoked responses were preserved very well in all cell types under these conditions, although the retinal slices were prepared under room light. Recordings were done within $2 \mathrm{hr}$ after preparation of the slices.

Superfusion. The slices were superfused continuously with oxygenated amphibian saline, which flowed through the chamber $(0.7 \mathrm{ml}$ in volume $)$ at a rate of $1.21 \mathrm{ml} / \mathrm{min}$. Saline consisted of (in $\mathrm{mM}$ ) $110 \mathrm{NaCl}, 2 \mathrm{KCl}, 2$ $\mathrm{CaCl}_{2}, 1 \mathrm{MgCl}_{2}, 5$ glucose, and $5 \mathrm{HEPES}$ titrated to $\mathrm{pH} 7.7$ with $\mathrm{NaOH}$. The control saline always contained $200 \mu \mathrm{M}$ picrotoxin and $0.5-10 \mu \mathrm{M}$ strychnine (both from Sigma, St. Louis, MO) to block the activation of GABA receptors and glycine receptors, respectively. All pharmacological agents were added to the control saline and bath-applied. D-2-Amino5-phosphonopentanoic acid (D-AP5), 6-cyano-7-nitroquinoxaline-2,3dione (CNQX), and cyclothiazide were purchased from Tocris Cookson (Bristol, UK). Stock solutions for picrotoxin, CNQX, and cyclothiazide were dissolved in dimethyl sulfoxide. The final concentration of dimethyl sulfoxide was always kept below $0.07 \%$.

Whole-cell patch-clamp recordings. Patch pipettes for whole-cell recordings were pulled on a horizontal puller (P97, Sutter Instruments, Novato, $\mathrm{CA}$ ) and had tips that were 7-12 $\mathrm{M} \Omega$ in the control saline when they were filled with the intracellular solution. The intracellular solution in the majority of experiments consisted of (in mM) 97.5-107.5 CsCl, $2 \mathrm{MgCl}_{2}$, $0.5 \mathrm{CaCl}_{2}$, 5 EGTA, 10 HEPES, 5 ATP disodium salt, 0.5 GTP sodium salt, and $0.25-0.5 \%$ Lucifer yellow, titrated to $\mathrm{pH} 7.8$ with $\mathrm{CsOH}$. In some experiments the intracellular $\mathrm{Cl}^{-}$concentration was lowered to 25 $\mathrm{mm}$ by replacing a portion of $\mathrm{CsCl}$ with $\mathrm{Cs}$-glutamate for bipolar cells and with $\mathrm{CsF}$ for GLCs, but we did not observe any experimental differences under these conditions. Liquid junction potential was corrected for all recordings.

A pair consisting of a bipolar cell and a GLC were whole-cell voltageclamped simultaneously with two patch-clamp amplifiers, CEZ 2300 (Nihon-Kohden, Tokyo, Japan) and EPC-7 (List, Darmstadt, Germany). Simultaneous recordings were extremely difficult $(\sim 1 \%$ success rate) in retinal slices, mainly because of the sticky substances that often prevented a tight seal (Edwards et al., 1989). Data presented in this paper were obtained from 26 cell pairs (bipolar cell and GLC), 9 single bipolar cells, and 22 single GLCs. Command voltage protocols were generated by using pCLAMP software (version 6.0.3, Axon Instruments, Foster City, CA). The $\mathrm{P} / \mathrm{N}$ leak subtraction method was applied for most current recordings from bipolar cells (i.e., 2-8 positive or negative pulses, $<12.5 \mathrm{mV}$ in amplitude, were applied before a test pulse to subtract the leak current). Current records typically were low-passfiltered at $1 \mathrm{kHz}$, digitized at $5 \mathrm{kHz}$, and stored in a hard disk of a computer (Prolinea 575, Compaq) and a DAT recorder (PC208Ax, Sony, Tokyo, Japan).

Fast capacitance compensation was adjusted to cancel the transient caused by the capacitance of the pipette. The series resistance and membrane capacitance were not always compensated, because electrical oscillations caused by overcompensation sometimes killed the cells. In a few cells the series resistance was found to be in the range between 20 and $50 \mathrm{M} \Omega$. To minimize dendritic filtering of EPSCs, we tried to choose a bipolar cell that had synaptic contact with the dendrites within 20-30 $\mu \mathrm{m}$ from the cell body of the GLC. By giving depolarizing step pulses to a bipolar cell, we sometimes observed large voltage escapes, resulting in an extraordinary large tail current in the bipolar cell. We excluded these data from analysis. Bipolar cells with short axons appeared to be spaceclamped better. However, resistance along the axon would have caused unavoidable space-clamp errors. The extent of this error could be estimated approximately by the following calculations. A cylindrical axon having a length of $40 \mu \mathrm{m}$, a diameter of $1 \mu \mathrm{m}$, and a resistivity of 250 $\mathrm{M} \Omega \cdot \mathrm{cm}$ has a resistance of $130 \mathrm{M} \Omega$ (see Mennerick et al., 1997). Therefore, a $50 \mathrm{pA}$ current in the terminal would cause a $6.5 \mathrm{mV}$ voltage drop.

Cell types were identified by their light-evoked responses and morphology, which was visualized after the recording by Lucifer yellow staining (see Fig. 1A). Bipolar cells could be distinguished morphologically from other retinal cells by the presence of an axon and a Landolt club. There were no significant differences between the EPSCs evoked by stimulating presynaptic ON-type bipolar cells and OFF-type bipolar cells.

In the newt retina $\sim 40 \%$ of the cells in the ganglion cell layer are known to be displaced amacrine cells (Ball and Dickson, 1983). We tried to choose cells with an apparent axon, but in most cases we could not discriminate between ganglion cells and displaced amacrine cells morphologically. Light-evoked responses of the cells in the ganglion cell layer were usually of ON/OFF transient type, and we rarely encountered ON-sustained type or OFF-type cells. Because light-evoked responses of $\mathrm{ON} / \mathrm{OFF}$ ganglion cells resemble those of ON/OFF transient amacrine cells (Werblin and Dowling, 1969), light-evoked responses were not useful for cell identification. The data seemed to be homogeneous, so we will abbreviate the phrase "cell in the ganglion cell layer" as GLC in this paper. Thus, all data shown here were obtained from pairs of either an ON-type or an OFF-type cell and an ON/OFF transient-type GLC.

\section{RESULTS}

A bipolar cell and a cell in the GLC were voltage-clamped simultaneously with a patch pipette. When the bipolar cell was depolarized from -66 to $-16 \mathrm{mV}$ for $50 \mathrm{msec}$, an inward postsynaptic current was evoked in the GLC voltage-clamped at $-76 \mathrm{mV}$ (Fig. $1 B$ ). Four consecutive voltage pulses evoked superimposable responses. When the interstimulus interval was longer than $30 \mathrm{sec}$, the postsynaptic currents were evoked without failure. Steady recordings usually were obtained for $>10 \mathrm{~min}$ (in the range between a few minutes and $30 \mathrm{~min}$ ).

\section{Neurotransmitter release from bipolar cell is $\mathrm{Ca}^{2+}$-dependent}

An increase in intracellular free $\mathrm{Ca}^{2+}$ concentration is essential for neurotransmitter release from most neurons (Katz and Miledi, 1969; Augustine and Charlton, 1986; Delaney and Zucker, 1990). We first examined whether $\mathrm{Ca}^{2+}$ influx is necessary for neurotransmitter release from retinal bipolar cells by blocking the $\mathrm{Ca}^{2+}$ current with extracellular $\mathrm{Co}^{2+}$.

When a bipolar cell was depolarized from -66 to $-16 \mathrm{mV}$ by a $50 \mathrm{msec}$ voltage pulse, a sustained inward current was activated in the bipolar cell, and, at the same time, an inward postsynaptic current was evoked in the GLC, voltage-clamped at $-76 \mathrm{mV}$ (Fig. $2 A)$. Substituting $\mathrm{Co}^{2+}$ for divalent cations in the control saline (Fig. 2B) blocked the sustained inward current recorded from the bipolar cell. Because the outward $\mathrm{K}^{+}$currents had been blocked by $\mathrm{Cs}^{+}$in the pipette solution, the inward current activated during depolarization in the control saline was carried mainly by $\mathrm{Ca}^{2+} . \mathrm{Ca}^{2+}$ channels with slow inactivation have been reported to be localized in synaptic terminals of bipolar cells in the tiger salamander (Maguire et al., 1989) and goldfish (Tachibana et al., 1993 ) retinas. Bath application of $\mathrm{Co}^{2+}$ solution also blocked the evoked postsynaptic current in the GLC (Fig. $2 B$ ). The blocking effects of $\mathrm{Co}^{2+}$ were reversible (Fig. $2 C$ ). This result suggests that neurotransmitter release from bipolar cells is $\mathrm{Ca}^{2+}$-dependent. 


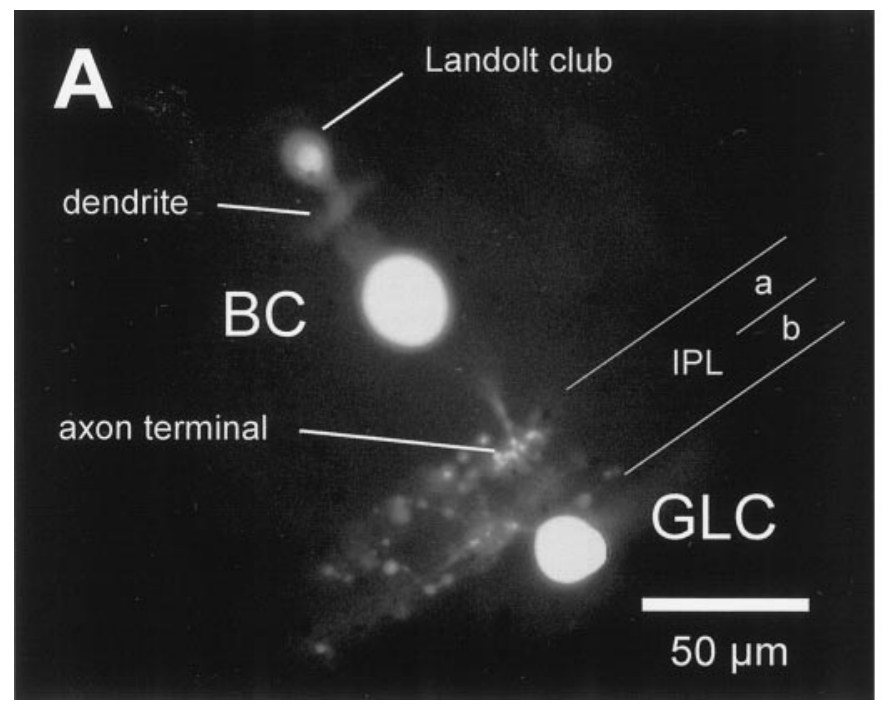

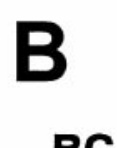

BC

\section{$50 \mathrm{~ms}$}

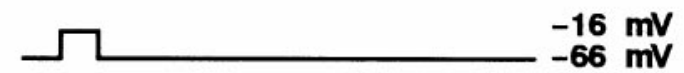

GLC

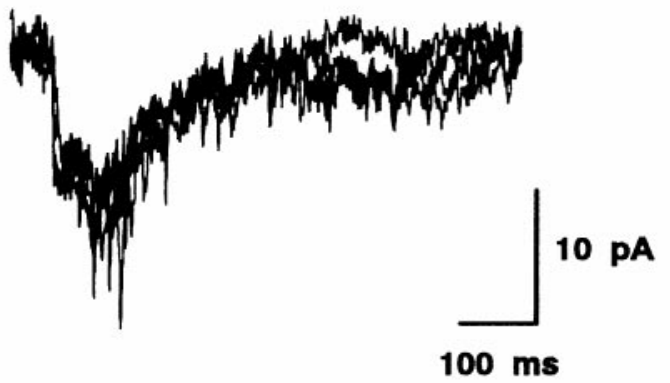

Figure 1. A, OFF bipolar cell and ON/OFF GLC pair stained with Lucifer yellow. The bipolar cell (BC) possesses a Landolt club and an axon, which are the criteria for distinguishing bipolar cells from other cell types. The axon terminal of this bipolar cell stratified in sublamina $a$ of the inner plexiform layer (IPL), indicating that the bipolar cell is of OFF type (Famiglietti et al., 1977). The dendrite of the cell in ganglion cell layer (GLC) stratified in both sublaminae $a$ and $b$ of the IPL, indicating that this cell is of the ON/OFF type. The axon of the bipolar cell and the dendrite of the GLC had synaptic contact in sublamina $a$. The patch pipettes were withdrawn for a better view. $B$, Depolarization of a single bipolar cell (from -66 to $-16 \mathrm{mV}$ for $50 \mathrm{msec}$; top trace) evoked an inward postsynaptic current (bottom trace) in the GLC, voltage-clamped at $-76 \mathrm{mV}$. Four consecutive current traces are superimposed. An interstimulus interval of $\sim 30 \mathrm{sec}$ was sufficient for stable recordings of the evoked currents.

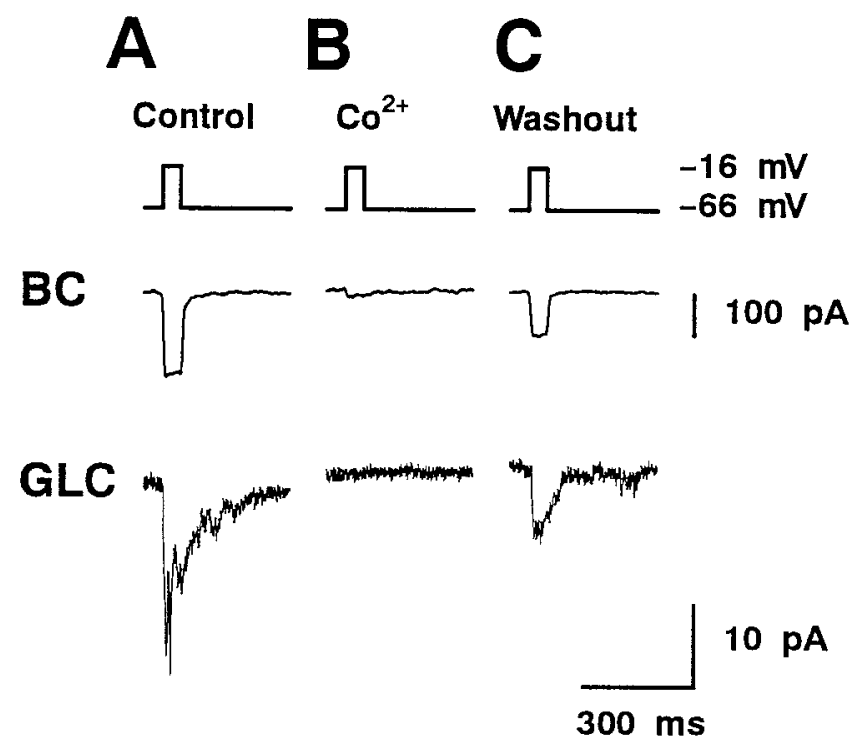

Figure 2. Blocking effects of $\mathrm{Co}^{2+}$ on the sustained inward current in a bipolar cell and the evoked postsynaptic current in a GLC. $A$, Depolarization (from -66 to $-16 \mathrm{mV}$ for $50 \mathrm{msec}$; top trace) of a bipolar cell activated a sustained inward current (middle trace) in the bipolar cell. The current traces of bipolar cell for this and the subsequent figures were obtained after the $\mathrm{P} / \mathrm{N}$ leak subtraction method. An inward postsynaptic current was evoked in the GLC, voltage-clamped at $-76 \mathrm{mV}$ (bottom trace). $B$, The sustained inward current in the bipolar cell and the evoked postsynaptic current in the GLC were blocked by substituting $3 \mathrm{mM} \mathrm{Co}^{2+}$ for divalent cations in the control solution. $C$, After the $\mathrm{Co}^{2+}$ was washed, the sustained inward current and the evoked postsynaptic current recovered partially in the bipolar cell and in the GLC, respectively.

To examine the relationship between the $\mathrm{Ca}^{2+}$ current $\left(I_{\mathrm{Ca}}\right)$ and the evoked postsynaptic current, we varied the magnitude of depolarizing pulses. Command voltage steps to potentials more positive than $-40 \mathrm{mV}$ activated $I_{\mathrm{Ca}}$; the maximal $I_{\mathrm{Ca}}$ was elicited at approximately $-20 \mathrm{mV}$ (Fig. $3 A$ ). The top graph in Figure $3 B$ shows the relationship between the command voltage applied to the bipolar cell and the peak amplitude of $I_{\mathrm{Ca}}$. The currentvoltage $(I-V)$ relationship of $I_{\mathrm{Ca}}$ resembled that of the L-type $\mathrm{Ca}^{2+}$ current described previously (Fox et al., 1987; Maguire et al., 1989; Tachibana et al., 1993) but was shifted to slightly more negative potentials. Large $I_{\mathrm{Ca}}$ may have caused a partial voltageclamp escape, resulting in a leftward shift of the $I-V$ curve (see Materials and Methods) (Mennerick et al., 1997).

The evoked postsynaptic current in GLCs showed a clear dependence on the amount of the $\mathrm{Ca}^{2+}$ influx into bipolar cells; the larger the amplitude of $I_{\mathrm{Ca}}$, the larger was the amplitude of the resulting postsynaptic current (Fig. $3 A$ ). The bottom graph in Figure $3 B$ shows the relationship between the command voltage applied to the bipolar cell and the peak amplitude of the postsynaptic current evoked in the GLC. The increment of both $I_{\mathrm{Ca}}$ and the evoked postsynaptic current was maximal when the command voltage of the bipolar cell was changed from -50 to $-35 \mathrm{mV}$. This voltage range is similar to the working range of bipolar cells in physiological conditions (i.e., the voltage range of photoresponses). These results indicate that bipolar cells and GLCs form a "normal" chemical synapse, which is $\mathrm{Ca}^{2+}$-dependent and which can be blocked completely by extracellular $\mathrm{Co}^{2+}$.

\section{Both non-NMDA receptors and NMDA receptors are activated by depolarization of single bipolar cells}

The neurotransmitter released from retinal bipolar cells is proposed to be the excitatory amino acid glutamate (Slaughter and Miller, 1983; Ehinger et al., 1988; Tachibana and Okada, 1991). Because GLCs of the newt and tiger salamander retinas respond to extracellularly applied kainate, AMPA, and NMDA (Gottesman and Miller, 1992; Matsui and Tachibana, 1997), both nonNMDA receptors and NMDA receptors seem to be present in GLCs. However, it is not yet clear whether both receptors function in signal transmission from bipolar cells to GLCs. To answer 


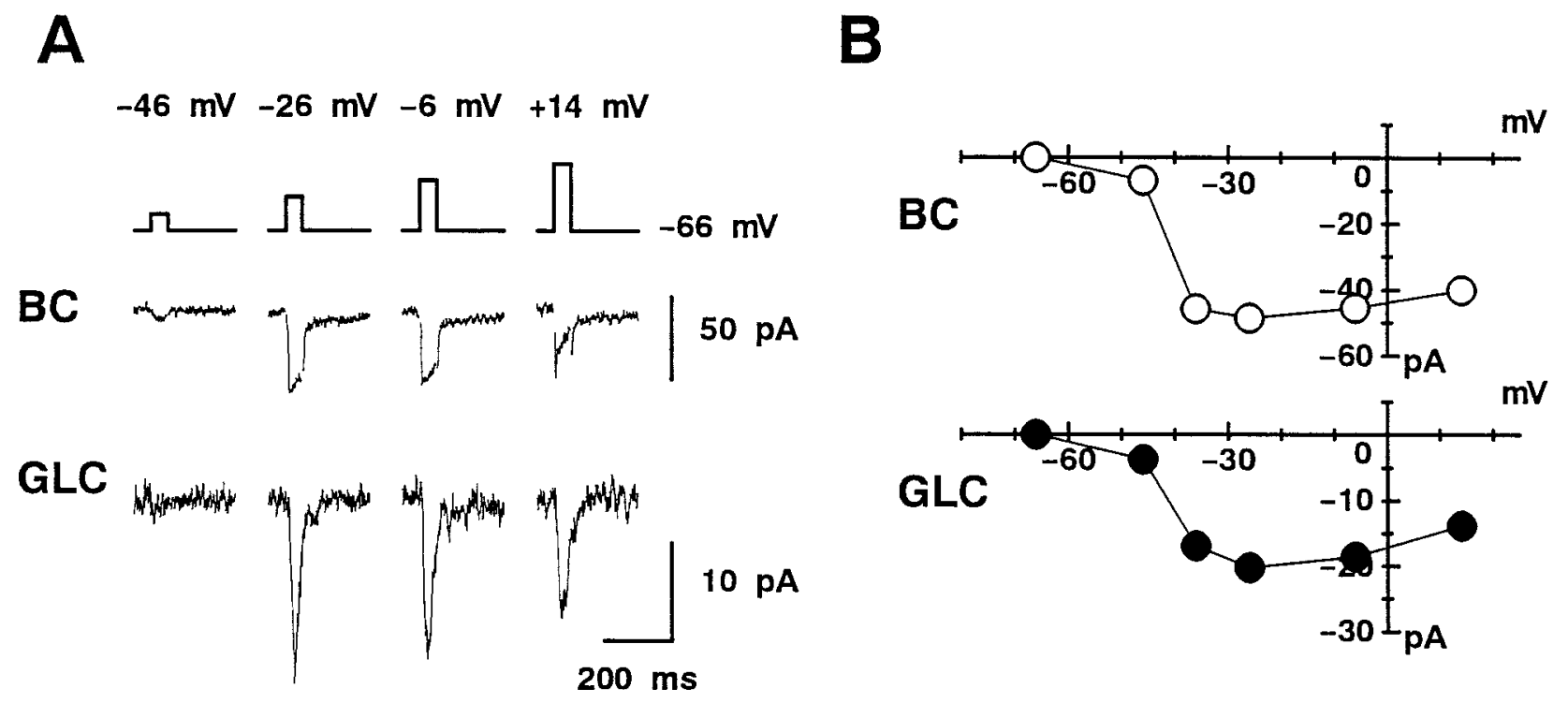

Figure 3. Relationship between $I_{\mathrm{Ca}}$ in a bipolar cell and the evoked postsynaptic current in a GLC. A, A bipolar cell was depolarized from the holding potential of $-66 \mathrm{mV}$ to various command voltages for $50 \mathrm{msec}$ (top trace). During depolarization, $I_{\mathrm{Ca}}$ (middle trace) was activated in the bipolar cell, and the evoked postsynaptic current (bottom trace) was observed in a GLC, voltage-clamped at $-76 \mathrm{mV}$. B. The peak amplitude of $I_{\mathrm{Ca}}$ (top graph, open circles) and the peak amplitude of the evoked postsynaptic current (bottom graph, solid circles) were plotted against the command voltage applied to the bipolar cell.
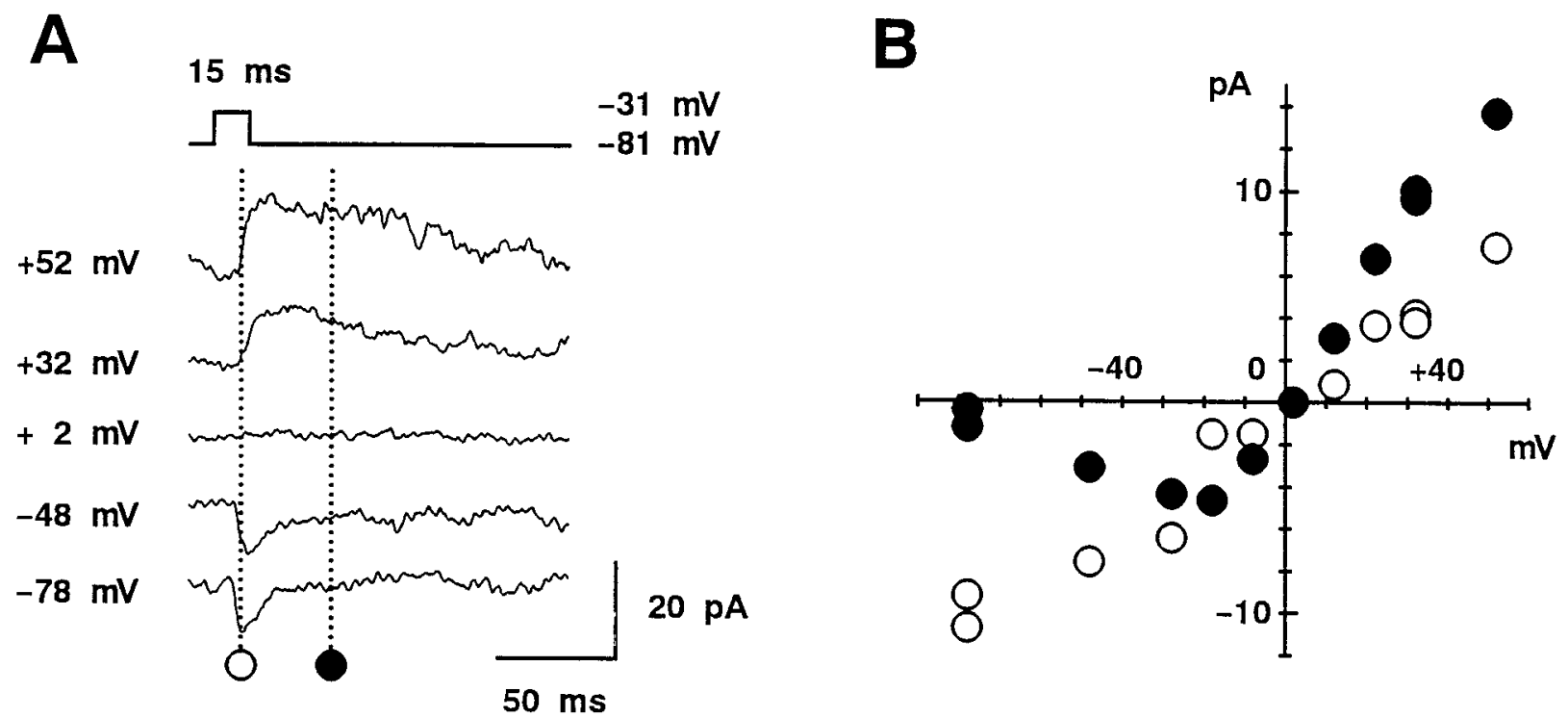

Figure 4. Two components of the evoked postsynaptic current. $A$, Postsynaptic currents were recorded from a GLC maintained at various potentials by applying depolarizing pulses (from -81 to $-31 \mathrm{mV}$ for $15 \mathrm{msec}$; top trace) to a bipolar cell. The holding potential of the GLC is indicated at the left of each evoked current trace (lower five traces). The traces were shifted arbitrarily for a better view. B, The amplitude of the evoked postsynaptic current was measured at $12 \mathrm{msec}$ (open circles) and $50 \mathrm{msec}$ ( filled circles) and is plotted against the holding potential of the GLC.

this question, we first examined the properties of the evoked postsynaptic current in GLCs.

A bipolar cell was depolarized from -81 to $-31 \mathrm{mV}$ for 15 msec to evoke the postsynaptic current in the GLC held at various command voltages (Fig. 4A). The depolarizing pulse was applied to the bipolar cell each time when the membrane current of the GLC reached a new steady level after the command voltage was changed. Although the bath solution always contained picrotoxin and strychnine to block inhibitory activities in the retina, a low $\mathrm{Cl}^{-}$pipette solution was used for recording the postsynaptic current from the GLC to discriminate between EPSCs and re- sidual IPSCs. The reversal potential of glutamate agonistinduced current was $\sim 0 \mathrm{mV}$ (Matsui and Tachibana, 1997), whereas $E_{\mathrm{Cl}}$ (the reversal potential expected for IPSC) was calculated to be $-39 \mathrm{mV}$ under our recording conditions. The measured reversal potential of the evoked postsynaptic currents was $-0.9 \pm 2.7 \mathrm{mV}$ (pooled data are expressed as mean $\pm \mathrm{SEM}$ unless otherwise mentioned; $n=7$ ). No postsynaptic current reversed its polarity near $E_{\mathrm{Cl}}$. Thus, the evoked postsynaptic currents recorded in GLCs were indeed excitatory.

The decay of the evoked EPSCs was faster at negative potentials than at positive potentials. For the cell illustrated in Figure 
A

B

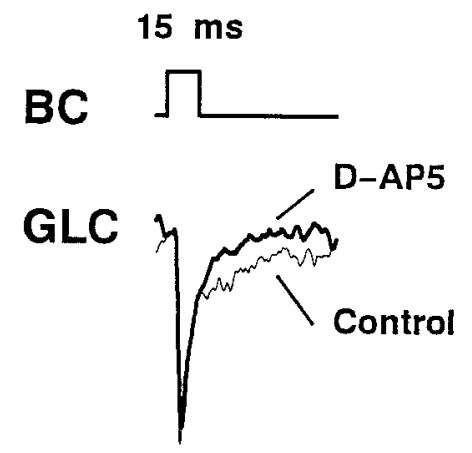

$15 \mathrm{~ms}$
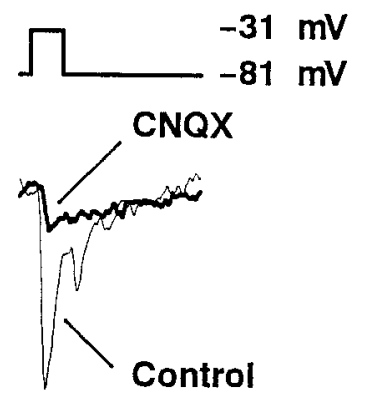

$10 \mathrm{pA}$

$50 \mathrm{~ms}$

Figure 5. Pharmacological separation of non-NMDA and NMDA receptor-mediated components of the evoked EPSCs. $A$, EPSCs (bottom traces) were evoked in a GLC maintained at $-78 \mathrm{mV}$ by applying voltage pulses (from -81 to $-31 \mathrm{mV}$ for $15 \mathrm{msec}$ ) to a bipolar cell (top trace). The late component of EPSC evoked in control saline (bottom trace, thin line) was blocked completely with the addition of $15 \mu \mathrm{M}$ D-AP5 to the bath solution (thick line). B, EPSCs recorded from the same cell pair as in $A$. After D-AP5 was washed out completely with control saline, EPSC recovered to the initial shape (bottom trace, thin line). When $2 \mu \mathrm{M} \mathrm{CNQX}$ was added to the bath solution, the early component of the EPSC disappeared (thick line).

$4 A$, the EPSC at $-78 \mathrm{mV}$ peaked at $12 \mathrm{msec}$ after the onset of the voltage pulse. The amplitude of EPSCs was measured at 12 and $50 \mathrm{msec}$ after the pulse onset and plotted as a function of the command voltage of the GLC (Fig. 4B). The $I-V$ relationship at $12 \mathrm{msec}$ (the early component of the evoked EPSC) was almost linear, whereas that at $50 \mathrm{msec}$ (the late component of the evoked EPSC) was J-shaped. The strong outward rectification of the late component is characteristic of NMDA receptor-mediated responses (Nowak et al., 1984).

Next, pharmacological agents were bath-applied to identify the subtype of glutamate receptors mediating the evoked EPSC in GLCs. A bipolar cell was depolarized from -81 to $-31 \mathrm{mV}$ for $15 \mathrm{msec}$ while the command voltage of a GLC was held constant at $-78 \mathrm{mV}$. D-AP5, a specific antagonist for NMDA receptors, eliminated the late component of the evoked EPSC while the early component remained fairly intact (Fig. 5A). On the other hand, CNQX, a specific antagonist for non-NMDA receptors, suppressed the early component but did not affect the late component (Fig. 5B). Similar results were obtained from six cell pairs. These results indicate that both non-NMDA receptors and NMDA receptors are activated in a GLC maintained at $-78 \mathrm{mV}$, when a single bipolar cell is depolarized for duration as brief as $15 \mathrm{msec}$.

\section{Spontaneous EPSCs are induced by the activation of non-NMDA receptors}

To investigate whether both non-NMDA receptors and NMDA receptors are colocalized at the postsynaptic membrane region facing each release site of a bipolar cell, we examined properties of spontaneous EPSCs. Small transient inward currents that occurred spontaneously often could be seen in GLCs voltageclamped at negative potentials (Fig. $6 A$ ). The frequency of these spontaneous events varied from cell to cell and ranged between 5 and $200 \mathrm{~Hz}$. When their frequency was high, analysis of spontaneous events was difficult to perform because the events frequently overlapped. Thus, continuous recordings obtained from GLCs with relatively low frequency and low membrane current noise were selected for the analysis of the waveform and amplitude of the spontaneous events.

An example of such recording from a GLC held at $-76 \mathrm{mV}$ is shown in Figure $6 A$. Only those events that were not overlapping and that could be isolated clearly were selected for further analysis. A peak amplitude histogram was constructed from these selected discrete events (Fig. 6B). The mean peak amplitude was $\sim 10 \mathrm{pA}$ for the cell illustrated and $8.7 \pm 1.0 \mathrm{pA}$ for 15 cells that were examined. The histogram was skewed slightly toward larger amplitudes. Similar skewed histograms have been reported in other neurons in the CNS (Bekkers and Stevens, 1989; McBain and Dingledine, 1992; Silver et al., 1992). Such skewing would be attributable partly to the sampling bias introduced by overlooking low amplitude events. The amplitude distribution of the baseline noise also is illustrated in Figure $6 \mathrm{~B}$. It is also possible that the cable properties of GLC dendrites might have distorted the peak amplitude histogram. With strong cable filtering, both the rise time and decay time would be expected to be slower for small amplitude events than for large amplitude events (Bekkers and Stevens, 1996). However, we found that neither the rise time from 10 to $90 \%$ of the peak nor the decay time was correlated with the peak amplitude of events (Fig. $6 \mathrm{C}$ ). Thus, variability in amplitude of spontaneous events cannot be attributed simply to cable filtering.

Alignment of 525 discrete events at their peaks allowed us to derive the average waveform of the spontaneous events (Fig. 6D). The time course of the decay of the average waveform and each individual event could be well fit with a single exponential function. The decay time constant of the average waveform was 2.6 msec for this cell and $3.1 \pm 0.4 \mathrm{msec}$ for 15 cells that were examined. It has been demonstrated that the NMDA component lasts much longer than the non-NMDA component (Bekkers and Stevens, 1989; McBain and Dingledine, 1992; Silver et al., 1992). If both non-NMDA receptors and NMDA receptors were colocalized at the postsynaptic membrane region facing each release site, the decay of spontaneous events should have followed a double exponential function.

To evaluate whether NMDA component is actually absent in spontaneous events recorded from GLCs, we applied glutamate antagonists. At positive potentials the membrane current became noisy; thus, the command voltage was set at $-46 \mathrm{mV}$ (Fig. $7 A-C$ ) to reduce the $\mathrm{Mg}^{2+}$ block of NMDA receptors (see Fig. $4 B$ ). The mean decay time constant of spontaneous events at $-46 \mathrm{mV}$ was $3.8 \pm 0.6 \mathrm{msec}(n=13)$ (Fig. $7 D)$, which was not significantly different from the value obtained at $-76 \mathrm{mV}$ (see above). Neither the amplitude nor the time course of the spontaneous events was changed by the application of $50 \mu \mathrm{M}$ D-AP5 (Fig. 7D). The cumulative amplitude distribution was nearly the same for both conditions (Fig. 7E). Similar data were obtained from four other GLCs. The addition of $5 \mu \mathrm{M}$ CNQX to the bath solution abolished spontaneously occurring events completely (Fig. 7C). The application of CNQX alone also eliminated the spontaneous events totally $(n=3)$. These results indicate that these spontaneous events are EPSCs, which are mediated mostly by the activation of non-NMDA receptors.

These results are consistent with those found in GLCs of the 

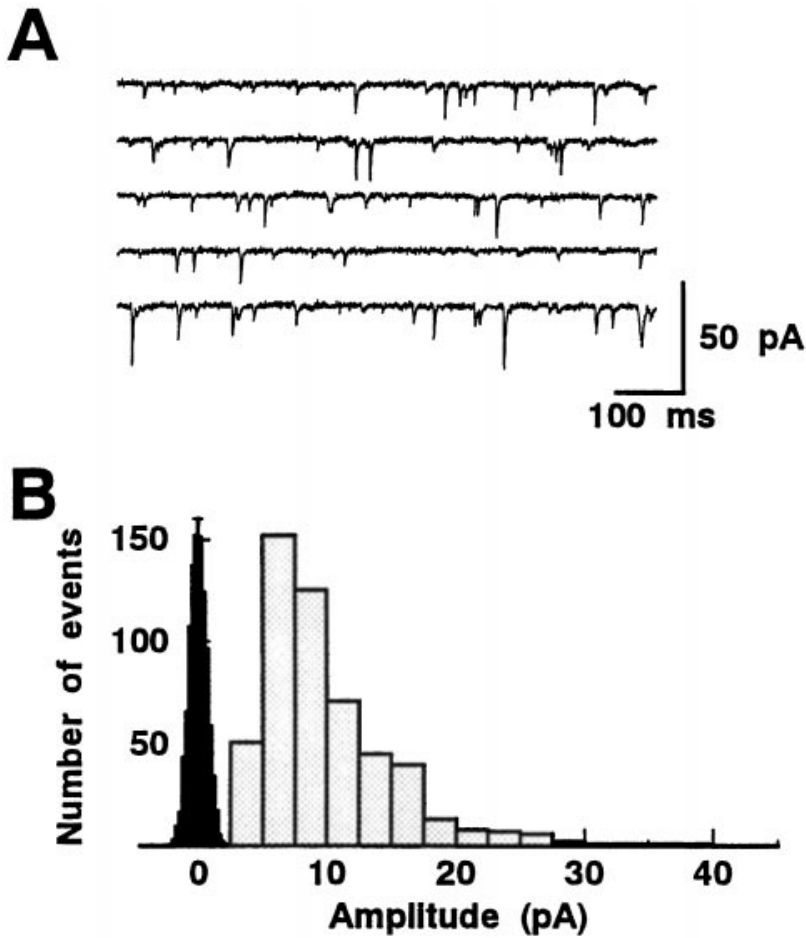

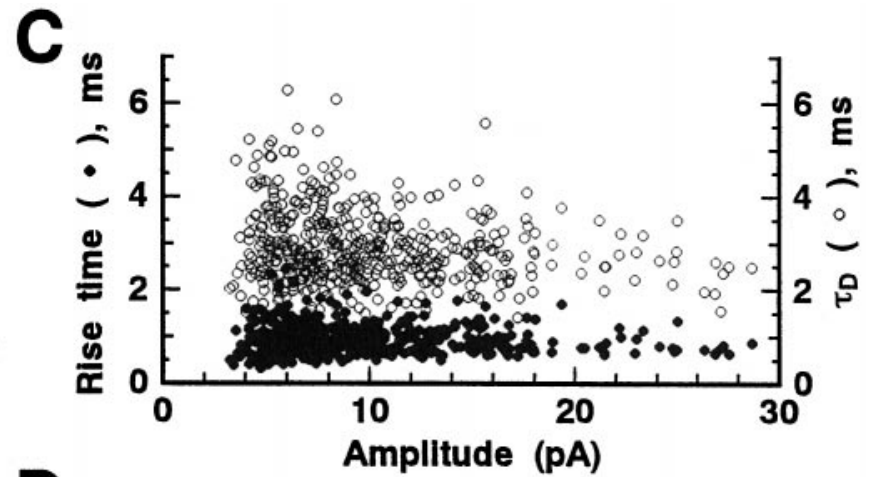

D

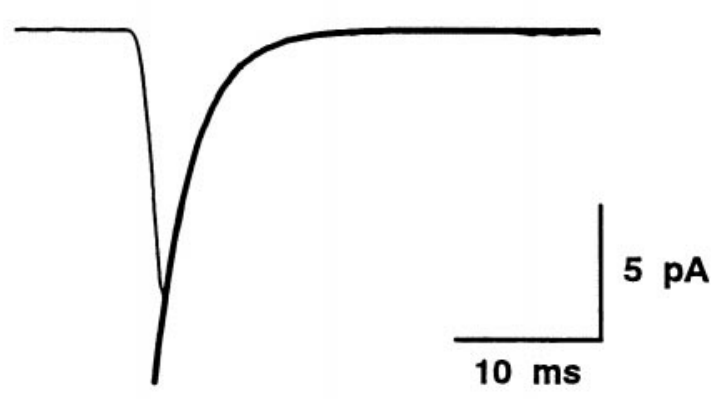

Figure 6. Characteristics of spontaneous EPSCs observed in GLCs. A, Five sets of continuous 800 msec current recordings were obtained from a GLC that was voltage-clamped at $-76 \mathrm{mV}$. B. The amplitude histogram (gray; bin width $2.5 \mathrm{pA}$ ) was constructed from 525 spontaneous EPSCs that could be isolated clearly. The amplitude histogram of the baseline noise (black; $\pm 0.7 \mathrm{pA} \mathrm{SD}$; bin width $0.25 \mathrm{pA}$ ) was taken from 10 (100 msec each) sections of the recording that apparently were devoid of the spontaneous events. The peak was set to match the peak of the spontaneous EPSC amplitude distribution. $C$, Rise times (the time required to change from 10 to $90 \%$ of the peak amplitude; filled circles) and decay time constants (open circles) were plotted against their peak amplitudes. $D$, An averaged waveform of the 525 spontaneous EPSCs aligned at their peaks (thin line). The falling phase was well fit by a single exponential function with the decay time constant of $2.6 \mathrm{msec}$ (thick line).

tiger salamander retina (Taylor et al., 1995). Taylor et al. (1995) hypothesized that non-NMDA receptors were segregated from NMDA receptors, which are located predominantly on the periphery of the dendritic arbor. They postulated that the lack of an NMDA component in spontaneous EPSCs results from the attenuation of the NMDA component by cable filtering. However, their hypothesis cannot account for our result that depolarization of a single bipolar cell activated both non-NMDA receptors and NMDA receptors of newt GLCs (see Figs. 4, 5). A more likely interpretation would be that non-NMDA receptors are located at the postsynaptic region immediately beneath each release site, whereas NMDA receptors are located slightly away from the region. Depolarization of a single bipolar cell may evoke simultaneous and/or multiquantal release of neurotransmitter from multiple release sites; thus, NMDA receptors in the regions slightly away from the release sites would be activated by the accumulated spilled-over neurotransmitter. When the neurotransmitter is released spontaneously, accumulation of spilled-over neurotransmitter may be too small to activate these NMDA receptors, resulting in the spontaneous EPSCs only with a nonNMDA component.

It should be noted that, when spontaneous vesicle fusion occurred successively with short intervals, there might have been enough accumulation of glutamate, which was sufficient to activate not only non-NMDA receptors but also NMDA receptors. However, this possibility was not examined, because we focused only on discrete events; thus, overlapping events were not analyzed in the present study.

\section{NMDA receptors are responsible for mediating prolonged neurotransmitter release}

We have demonstrated that depolarizing a single bipolar cell activates both non-NMDA receptors and NMDA receptors of a GLC (see Figs. 4, 5). However, analysis of spontaneous EPSCs suggested that non-NMDA receptors and NMDA receptors would not be quite colocalized within each postsynaptic region. Unlike spiking neurons, bipolar cells respond to photo stimuli with graded potentials under physiological conditions (Werblin and Dowling, 1969). Thus, it seems important to know the activation time course of each receptor type when a single bipolar cell is depolarized for a prolonged period. First, we examined the relationship between the duration of depolarizing pulses applied to a single bipolar cell and the evoked EPSC in the postsynaptic GLC.

A bipolar cell was depolarized from -66 to $-16 \mathrm{mV}$ for various durations (Fig. $8 A$ ). $I_{\mathrm{Ca}}$ recorded from the bipolar cell decayed only slightly during the depolarization, indicating that the $\mathrm{Ca}^{2+}$ influx occurred at an approximately constant rate throughout the depolarization. The amplitude of the evoked EPSC immediately after the onset of the depolarizing pulse was saturated for pulses longer than $10 \mathrm{msec}$. However, the decay rate of the evoked EPSC was slowed as the pulse duration was increased. In Figure $8 B$, the time integral (charge) of the evoked EPSC was plotted against the pulse duration. The data were obtained from seven cell pairs and normalized to the charge of EPSCs evoked by $50 \mathrm{msec}$ pulses. The data points could be fit with a linear function in the range of duration between 10 and 150 msec. This suggests that the amount of neurotransmitter released 


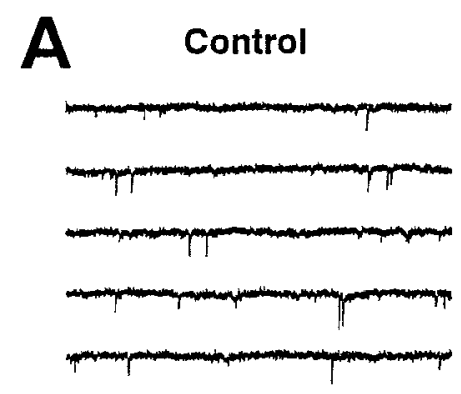

D
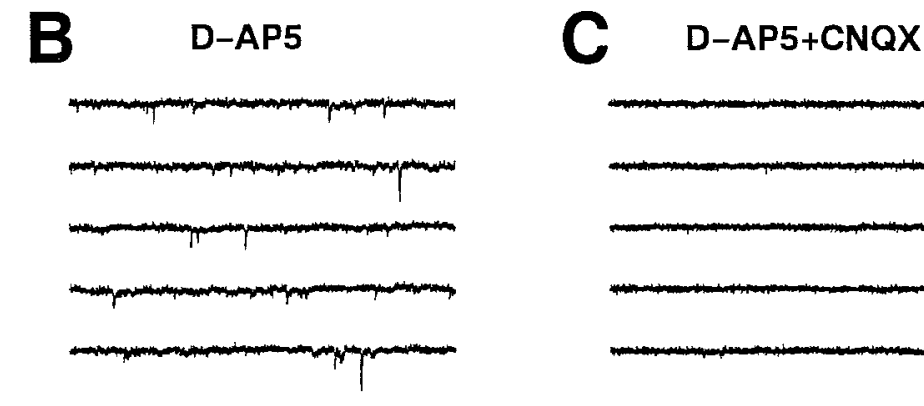

D-AP5+CNQX

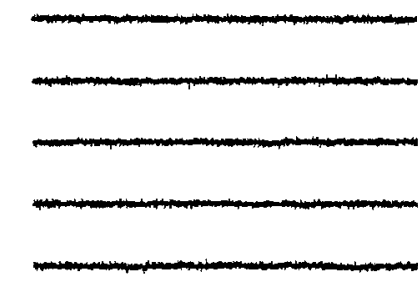

$20 \mathrm{pA}$

$200 \mathrm{~ms}$

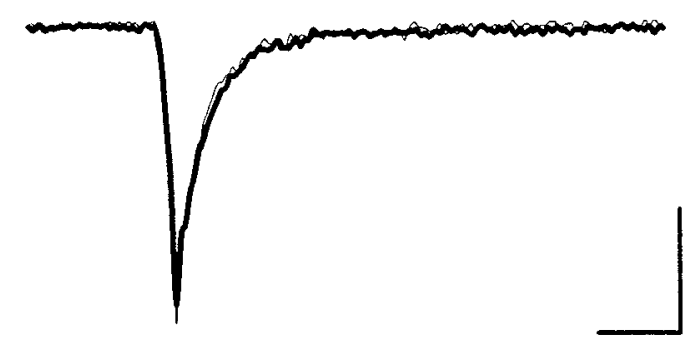

$10 \mathrm{~ms}$

\section{2 pA}
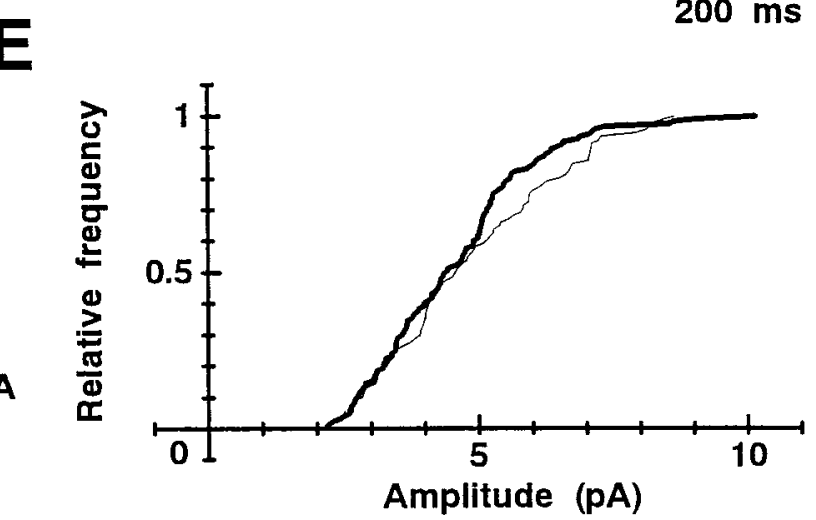

Figure 7. Spontaneous EPSCs are mediated by non-NMDA receptors. $A-C$, Five sets of continuous 2 sec current recordings for each condition were obtained from a GLC voltage-clamped at $-46 \mathrm{mV}$. $A$, Control saline. $B$, D-AP5 $(50 \mu \mathrm{M})$ affected neither the frequency nor the amplitude of the spontaneous EPSCs. $C$, The addition of CNQX $(5 \mu \mathrm{M})$ to the D-AP5 solution abolished all spontaneous events. $D$, The average waveform of the spontaneous EPSCs in control saline $(n=91$; thin line $)$ is superimposed on that in the presence of D-AP5 $(n=125$; thick line). The decay phase overlapped for both conditions. E, Cumulative amplitude distribution of spontaneous EPSCs was examined in control saline (thin line) and in the presence of D-AP5 (thick line).
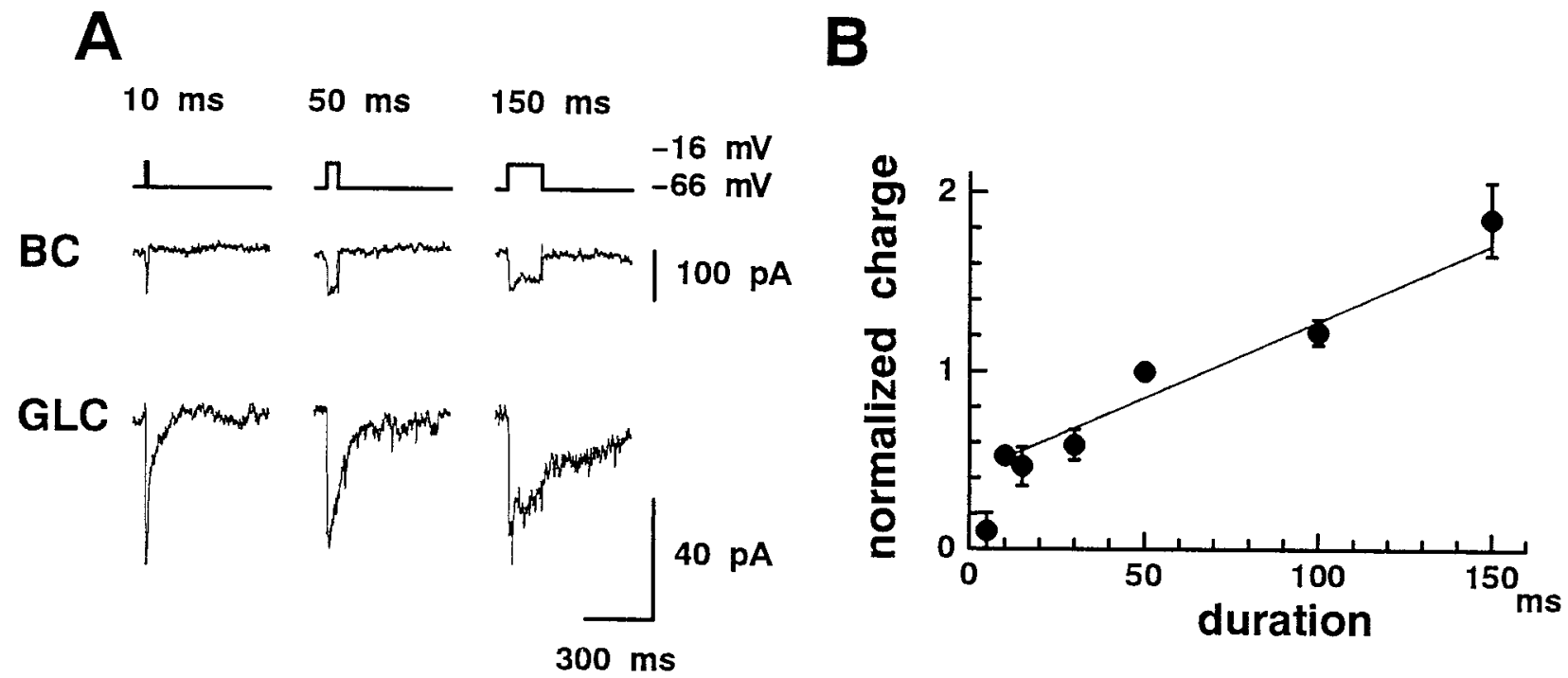

Figure 8. Time integral of EPSC (response charge) increases with increasing stimulus duration. $A$, A bipolar cell was depolarized from -66 to $-16 \mathrm{mV}$ for various durations (top trace). $I_{\mathrm{Ca}}$ decayed only slightly during depolarization (middle trace). The membrane potential of a GLC was held at $-76 \mathrm{mV}$. The initial peak amplitude of the evoked EPSC (bottom trace) was already saturated with the $10 \mathrm{msec}$ pulse, and the decay of EPSC became slower with longer pulses. $B$, The relationship between the pulse duration and the normalized response charge (time integral of EPSC). The data were obtained from seven cell pairs and normalized to the response charge for the $50 \mathrm{msec}$ pulse. The error bars represent the SEM. The data points could be fit with a linear function in the range between 10 and $150 \mathrm{msec}$.

from bipolar cells increases with increasing stimulus duration. The linear regression line did not cross the origin (Fig. 8B). This may be attributable to the proposed existence of a small rapid component of exocytosis before a relatively large delayed com- ponent in retinal bipolar cells (Mennerick and Matthews, 1996; Sakaba et al., 1997).

Because two types of receptors with different properties mediated the evoked EPSCs, we next selectively blocked NMDA 


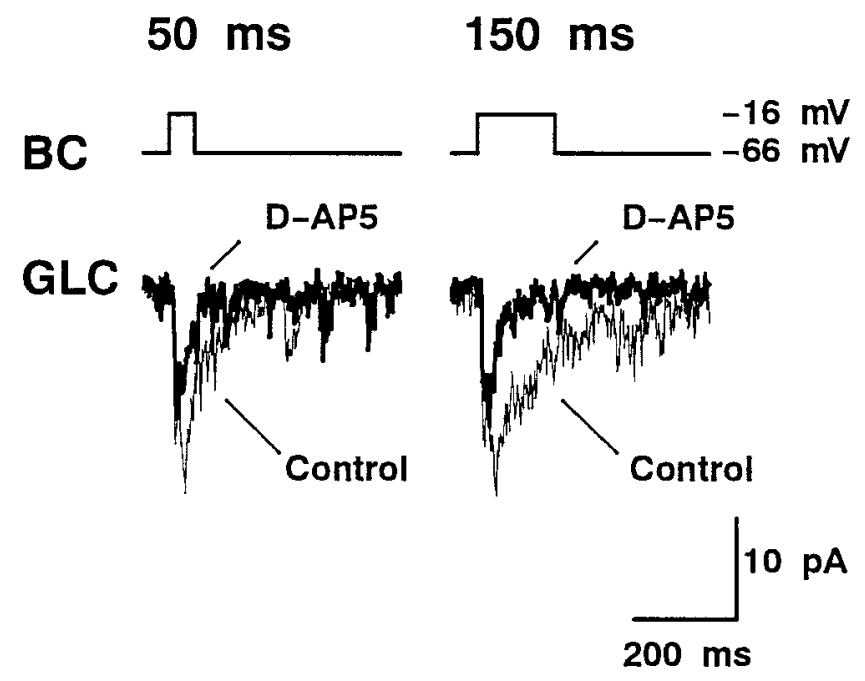

Figure 9. Effect of D-AP5 on the evoked EPSCs. A bipolar cell was depolarized from -66 to $-16 \mathrm{mV}$ for $50 \mathrm{msec}$ (left) or for $150 \mathrm{msec}$ (right) in the absence (Control, thin line) or presence of $50 \mu \mathrm{M}$ D-AP5 (thick line). D-AP5 selectively blocked the late component of the evoked EPSCs recorded from a GLC maintained at $-76 \mathrm{mV}$.

receptors with D-AP5 to evaluate the contribution of each receptor type to the evoked EPSC. A bipolar cell was depolarized from -66 to $-16 \mathrm{mV}$ for various durations in the absence and presence of $50 \mu \mathrm{M}$ D-AP5 (Fig. 9). The non-NMDA receptor-mediated component, evidenced by its persistence in the presence of D-AP5, decayed quickly during the pulse. On the other hand, the D-AP5-sensitive component increased with duration of the depolarizing pulse, indicating that NMDA receptors are responsible for maintaining the late phase of the evoked EPSC. Similar results were obtained from four cell pairs.

\section{Non-NMDA receptors are desensitized during stimuli of long duration}

In the previous section it was suggested that the early component of the evoked EPSC was mediated by the activation of nonNMDA receptors. The peak amplitude of the evoked EPSC did not change appreciably as the pulse duration was increased (Fig. 9). It has been demonstrated that non-NMDA receptors desensitize very quickly in the sustained presence of glutamate (Trussell et al., 1988; Jones and Westbrook, 1996). To investigate whether the rapid desensitization of non-NMDA receptors is a limiting factor of non-NMDA receptor-mediated excitation, we examined the effect of cyclothiazide on the evoked EPSC. Cyclothiazide is known to slow the desensitization of non-NMDA receptors with little effect on their deactivation rate (Trussell et al., 1993; Yamada and Tang, 1993) (but see Patneau et al., 1993).

A bipolar cell was depolarized from -66 to $-16 \mathrm{mV}$ for various durations either in the presence of $50 \mu \mathrm{M}$ D-AP5 alone or in the presence of both $50 \mu \mathrm{M}$ D-AP5 and $100 \mu \mathrm{M}$ cyclothiazide (Fig. 10). The non-NMDA receptor-mediated EPSCs, which were isolated by D-AP5, were strongly affected by cyclothiazide: their amplitude was enhanced, and their decay was slowed. For 50 msec depolarizing pulses, the amplitude increased $2.2 \pm 0.6$ times, the decay time constant increased from $25.4 \pm 14.7 \mathrm{msec}$ (without cyclothiazide) to $144.8 \pm 12.4 \mathrm{msec}$ (with cyclothiazide), and the total charge of the EPSCs increased $5.6 \pm 4.4$ times $(n=$ 4). This result indicates that desensitization plays a major role in shaping the non-NMDA receptor-mediated component of EPSCs.

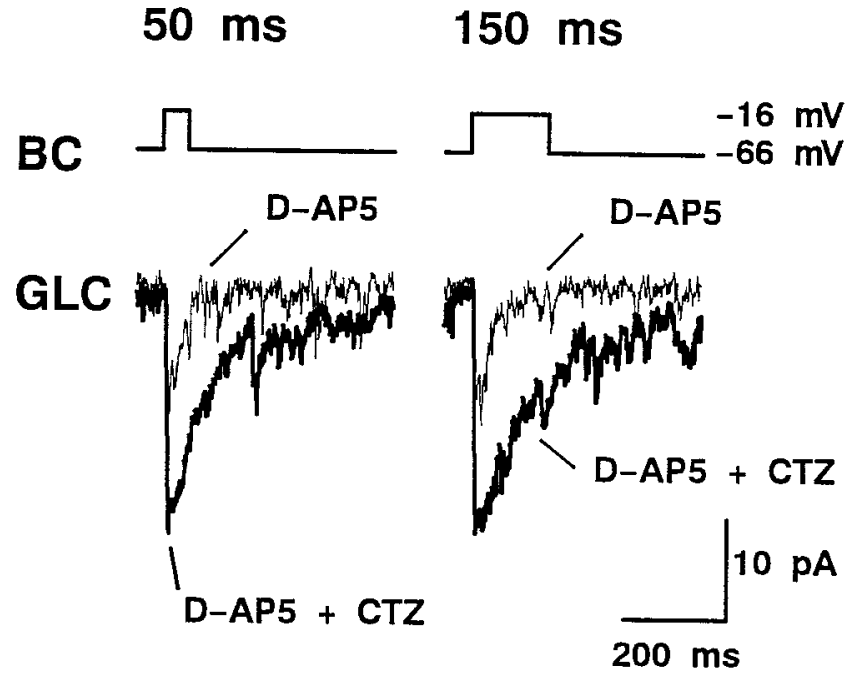

Figure 10. Effect of cyclothiazide (CTZ) on the non-NMDA receptormediated component of the evoked EPSCs. EPSCs were recorded from the same cell pair as shown in Figure 9. A bipolar cell was depolarized from -66 to $-16 \mathrm{mV}$ for 50 or $150 \mathrm{msec}$ (top trace) either in the presence of $50 \mu \mathrm{M}$ D-AP5 alone (thin line) or in the presence of both $50 \mu \mathrm{M}$ D-AP5 and $100 \mu \mathrm{M}$ cyclothiazide (thick line). Non-NMDA receptor-mediated EPSCs were recorded from a GLC maintained at $-76 \mathrm{mV}$. Cyclothiazide enhanced the amplitude and prolonged the decay of the evoked EPSCs.

However, it has to be noted that, in absence of cyclothiazide, the decay time constant of the non-NMDA receptor-mediated component of EPSC during a $150 \mathrm{msec}$ pulse $(25.8 \pm 3.1 \mathrm{msec}$; $n=6$ ) was much slower than the rate of non-NMDA receptor desensitization reported elsewhere (1.7-16.3 msec; Geiger et al., 1995; Silver et al., 1996). This result suggests that some nonNMDA receptors of GLCs also may experience slow and low glutamate concentration change during the depolarization of a bipolar cell. It is interesting to note that, in the presence of cyclothiazide, the decay time constant $(144.8 \pm 24.8 \mathrm{msec} ; n=6)$ of the non-NMDA receptor-mediated EPSC after the $50 \mathrm{msec}$ pulse was also much slower than the rate of non-NMDA receptor deactivation reported elsewhere (0.6-3.3 msec; Geiger et al., 1995; Silver et al., 1996). This result suggests that some nonNMDA receptors also may locate in the region slightly away from the release sites. However, this slow decay of EPSC may be partially attributable to space-clamp errors, resulting in a slower repolarization of membrane potential at the synaptic terminal.

It has been suggested that cyclothiazide also has presynaptic actions to enhance neurotransmitter release (Diamond and Jahr, 1995). However, in the newt bipolar cells the amplitude of $I_{\mathrm{Ca}}$ induced by depolarization to $-16 \mathrm{mV}$ decreased to $81.9 \pm 3.7 \%$ $(n=9)$ in the presence of cyclothiazide. The $I_{\mathrm{Ca}}-V$ relationship did not shift in either direction along the voltage axis (data not shown). The decrease in $I_{\mathrm{Ca}}$ might have been caused by rundown because $I_{\mathrm{Ca}}$ did not recover well after the superfusate was changed back to the control saline. These results demonstrate that application of cyclothiazide at least did not enhance the $\mathrm{Ca}^{2+}$ influx through the $\mathrm{Ca}^{2+}$ channels in newt bipolar cells.

\section{DISCUSSION}

In the present study we performed dual whole-cell voltage-clamp recordings from synaptically connected bipolar cell and GLC pairs in the newt retinal slice preparation. Analyzing the properties of EPSCs evoked by depolarizing single bipolar cells and 
spontaneous EPSCs, we propose that only non-NMDA receptors of GLCs are localized at the postsynaptic region immediately beneath each release site of bipolar cells and that the NMDA receptors are localized slightly away from the region.

\section{$\mathrm{Ca}^{2+}$ dependence of neurotransmitter release}

The evoked EPSC at the GLC by depolarizing a single bipolar cell was blocked completely by the extracellular application of $\mathrm{Co}^{2+}$ (see Fig. 2). This indicates that the synaptic transmission from a bipolar cell to a GLC is performed via a "normal" chemical synapse, which is $\mathrm{Ca}^{2+}$-dependent. This finding is different from the photoreceptor synapse, where it was suggested that neurotransmitter could be released from photoreceptors under unfavorable conditions for the entry of $\mathrm{Ca}^{2+}$ into presynaptic terminals (Schwartz, 1986).

High-threshold, slowly inactivating L-type $\mathrm{Ca}^{2+}$ channels are reported to be localized at the axon terminals of bipolar cells in the tiger salamander (Maguire et al., 1989) and goldfish (Tachibana et al., 1993) retinas and have been proposed to be responsible for neurotransmitter release. The $I_{\mathrm{Ca}}$ of newt bipolar cells showed similar properties (see Fig. 3). However, electrophysiological properties alone are not strong enough to identify the subtype of $\mathrm{Ca}^{2+}$ channels, because these properties might have been distorted by an imperfect space clamp (Mennerick et al., 1997).

The increment of both the $I_{\mathrm{Ca}}$ of a bipolar cell and the EPSC evoked in the GLC was maximal when the command voltage of the bipolar cell was in the range between -50 and $-35 \mathrm{mV}$ (see Fig. $3 B$ ). This indicates that the synaptic gain in this voltage range is large, consistent with reports in rod output synapse (Attwell et al., 1987; Belgum and Copenhagen, 1988). Because the dynamic range of bipolar cells in physiological conditions is between -50 and $-30 \mathrm{mV}$ (Werblin and Dowling, 1969; Schwartz, 1974), such large synaptic gain in this voltage range seems reasonable.

\section{Physiological role for two distinct types of glutamate receptors}

The relationship between the pulse duration applied to a bipolar cell and the charge of evoked EPSCs turned out to be almost linear in the range between 10 and $150 \mathrm{msec}$ (see Fig. 8B). It is interesting to note that, in goldfish retinal bipolar cells, the amplitude of the membrane capacitance jumps recorded after a depolarizing pulse increased linearly with the pulse duration up to $200 \mathrm{msec}$ (von Gersdorff and Matthews, 1994). This membrane capacitance jump is proposed to be associated with exocytosis of synaptic vesicles. If we extend this linearity of the amount of neurotransmitter release to newt bipolar cells, it follows that non-NMDA receptors and NMDA receptors of GLCs may cooperate to translate the amount of neurotransmitter released from bipolar cells linearly to the input charge to GLCs.

Non-NMDA receptors have fast onset kinetics, whereas NMDA receptors respond slowly to a concentration change of glutamate. Therefore, it seems likely that the activation of nonNMDA receptors may reflect the high-frequency component of the signal generated by bipolar cells, whereas the activation of NMDA receptors may reflect the low-frequency component. However, because non-NMDA receptors desensitize quickly during the prolonged presence of glutamate, the cessation of an excitatory signal after the termination of neurotransmitter release will depend entirely on the deactivation kinetics of NMDA receptors. Rapid deactivation of NMDA receptors is thus essential for the combined NMDA receptors and non-NMDA receptors to act as an ideal bandpass filter. However, this is unlikely, because the deactivation time constant of NMDA receptor $(\sim 90 \mathrm{msec}$; Lester et al., 1990) is totally limited by the slow unbinding of glutamate from the receptor. Therefore, inhibitory inputs from amacrine cells to GLCs, which were blocked pharmacologically in the present experiments, might play an important role in the termination of the excitatory signal generated by bipolar cells.

\section{Distribution of non-NMDA receptors and NMDA receptors over the GLC dendrites}

Spontaneous EPSCs were mediated mainly by the activation of non-NMDA receptors; there was little or no contribution of NMDA receptors (see Figs. 6, 7). Similar results were reported in GLCs of the tiger salamander retina (Taylor et al., 1995). The present results suggest that only non-NMDA receptors are expressed in the postsynaptic regions immediately beneath the release sites of bipolar cells. Non-NMDA receptors have relatively low affinity for glutamate (Jonas and Sakmann, 1992; Häusser and Roth, 1997), whereas NMDA receptors have much higher affinity (Patneau and Mayer, 1990). Therefore, nonNMDA receptors coaggregated at the postsynaptic membrane regions may respond reliably to the neurotransmitter released from release sites.

The present study has demonstrated that a depolarizing pulse as brief as $15 \mathrm{msec}$ applied to a single bipolar cell activates both non-NMDA receptors and NMDA receptors of a postsynaptic GLC (see Figs. 4, 5). Because the branching of the bipolar cell axon terminals we studied was usually $<20 \mu \mathrm{m}$ in diameter, which is much smaller than the dendritic arbor of a GLC $(\sim 50-200$ $\mu \mathrm{m}$ ), we conclude that non-NMDA receptors and NMDA receptors are not separated widely.

There exist multiple active zones in a single bipolar cell terminal (von Gersdorff et al., 1996), and multiple bipolar cells contact with a single GLC at the dendrites. The stimulation of a bipolar cell with a depolarizing pulse may induce simultaneous exocytosis of multiple synaptic vesicles from multiple release sites. Thus, it can be imagined that neurotransmitter diffused from active zones activates the NMDA receptors slightly away from the release sites. Such phenomenon, which is often called "spill-over" or "cross-talk" has been proposed to exist in some synapses, especially where the release probability is high (Faber and Korn, 1988; Trussell et al., 1993; Barbour and Häusser, 1997). This idea seems to be supported by the present observations that spontaneous EPSCs consisted mainly of the non-NMDA receptor-mediated component (see Figs. 6, 7) and that the contribution of NMDA receptor-mediated component became prominent in the evoked EPSCs with increasing depolarizing pulse duration (see Figs. 8, 9).

\section{Desensitization of non-NMDA receptors}

There are conflicting reports concerning the time course of the non-NMDA receptor-mediated EPSC; it is determined by the deactivation rate of the non-NMDA receptors at some synapses (Silver et al., 1996) and by the desensitization rate at other synapses (Trussell et al., 1993). The discrepancy probably arises from the different time course of glutamate concentration change at the synaptic cleft. If the diffusion or uptake of released glutamate is fast enough, the deactivation time constant would determine the time course of the EPSC, whereas if the removal of glutamate is slower than the desensitization rate, desensitization would be the major determining factor.

For depolarizing pulses shorter than $150 \mathrm{msec}$, neurotransmit- 
ter released from a bipolar cell seems to increase in proportion to the pulse duration (see Fig. $8 B$ ). The prolonged high glutamate concentration at the synaptic cleft may desensitize the nonNMDA receptors significantly. In the presence of D-AP5, the non-NMDA component of the evoked EPSC decayed quickly during the pulse and did not increase much with increasing pulse duration (see Fig. 9). However, the decay time constant $(\sim 25$ msec) for the evoked EPSCs during the pulse was much slower than the reported desensitization time constant of non-NMDA receptors (1.7-16.3 msec; Geiger et al., 1995; Silver et al., 1996). Desensitization time constant should be slower if it is measured with lower concentration of glutamate rather than with the saturating dose (millimolar order). The response time course also depends on the rate of neurotransmitter release during depolarization and the spatial distribution of receptors relative to the release sites. Because the decay rate of evoked EPSC was increased greatly by the application of cyclothiazide (see Fig. 10), we conclude that desensitization is a major factor in shaping the non-NMDA receptor-mediated component of evoked EPSC.

The decay time constant $(\sim 150 \mathrm{msec})$ of the non-NMDA receptor-mediated component in the presence of cyclothiazide was much slower than the deactivation time constant of nonNMDA receptors (0.6-3.3 msec; Geiger et al., 1995; Silver et al., $1996)$ or the decay time constant of spontaneous EPSCs $(\sim 3$ msec). Thus, the glutamate concentration change, which nonNMDA receptors experience after the cessation of the depolarizing pulse, may be relatively slow. It can be estimated from the diff usion equations that the glutamate concentration change will be slowed significantly if spill-over occurs (Barbour and Häusser, 1997). The present result may be interpreted by the spill-over hypothesis that the spilled-over neurotransmitter also affects the activation of non-NMDA receptors. However, an alternative interpretation would be to assume the asynchronous neurotransmitter release that persists even after the cessation of a depolarizing pulse (Gleason et al., 1994; Borges et al., 1995). We do not know whether spill-over or asynchronous release is the major factor determining the decay time course of glutamate concentration at the synaptic cleft. It is interesting to note, however, that neurotransmitter release from goldfish retinal bipolar cells seems to terminate quickly after repolarization (Sakaba et al., 1997) (but see also Lagnado et al., 1996).

\section{REFERENCES}

Aizenman E, Frosch MP, Lipton SA (1988) Responses mediated by excitatory amino acid receptors in solitary retinal ganglion cells from rat. J Physiol (Lond) 396:75-91.

Attwell D, Borges S, Wu SM, Wilson M (1987) Signal clipping by the rod output synapse. Nature 328:522-524.

Augustine GJ, Charlton MP (1986) Calcium dependence of presynaptic calcium current and postsynaptic response at the squid giant synapse. J Physiol (Lond) 381:619-640.

Ball AK, Dickson DH (1983) Displaced amacrine and ganglion cells in the newt retina. Exp Eye Res 36:199-213.

Barbour B, Häusser M (1997) Intersynaptic diffusion of neurotransmitter. Trends Neurosci 20:377-384.

Bekkers JM, Stevens CF (1989) NMDA and non-NMDA receptors are co-localized at individual excitatory synapses in cultured rat hippocampus. Nature 341:230-233.

Bekkers JM, Stevens CF (1996) Cable properties of cultured hippocampal neurons determined from sucrose-evoked miniature EPSCs. J Neurophysiol 75:1250-1255.

Belgum JH, Copenhagen DR (1988) Synaptic transfer of rod signals to horizontal and bipolar cells in the retina of the toad (Bufo marinus). J Physiol (Lond) 396:225-245.

Borges S, Gleason E, Turelli M, Wilson M (1995) The kinetics of quan- tal transmitter release from retinal amacrine cells. Proc Natl Acad Sci USA 92:6896-6900.

Cohen ED, Zhou ZJ, Fain GL (1994) Ligand-gated currents of alpha and beta ganglion cells in the cat retinal slice. J Neurophysiol 72:1260-1269.

Coleman PA, Miller RF (1988) Do $N$-methyl-D-aspartate receptors mediate synaptic responses in the mudpuppy retina? J Neurosci 8:4728-4733.

Delaney KR, Zucker RS (1990) Calcium released by photolysis of DMnitrophen stimulates transmitter release at squid giant synapse. J Physiol (Lond) 426:473-498.

Diamond JS, Jahr CE (1995) Asynchronous release of synaptic vesicles determines the time course of the AMPA receptor-mediated EPSC. Neuron 15:1097-1107.

Edwards FA, Konnerth A, Sakmann B, Takahashi T (1989) A thin slice preparation for patch-clamp recordings from neurones of the mammalian central nervous system. Pflügers Arch 414:600-612.

Ehinger B, Ottersen OP, Storm-Mathisen J, Dowling JE (1988) Bipolar cells in the turtle retina are strongly immunoreactive for glutamate. Proc Natl Acad Sci USA 85:8321-8325.

Faber DS, Korn H (1988) Synergism at central synapses due to lateral diffusion of transmitter. Proc Natl Acad Sci USA 85:8708-8712.

Famiglietti Jr EV, Kaneko A, Tachibana M (1977) Neuronal architecture of on and off pathways to ganglion cells in carp retina. Science 198:1267-1269.

Fox AP, Nowycky MC, Tsien RW (1987) Kinetic and pharmacological properties distinguishing three types of calcium currents in chick sensory neurones. J Physiol (Lond) 394:149-172.

Geiger JRP, Melcher T, Koh D-S, Sakmann B, Seeburg PH, Jonas P, Monyer H (1995) Relative abundance of subunit mRNAs determines gating and $\mathrm{Ca}^{2+}$ permeability of AMPA receptors in principal neurons and interneurons in rat CNS. Neuron 15:193-204.

Gleason E, Borges S, Wilson M (1994) Control of transmitter release from retinal amacrine cells by $\mathrm{Ca}^{2+}$ influx and efflux. Neuron 13:1109-1117.

Gottesman J, Miller RF (1992) Pharmacological properties of $N$-methylD-aspartate receptors on ganglion cells of an amphibian retina. J Neurophysiol 68:596-604.

Häusser M, Roth A (1997) Dendritic and somatic glutamate receptor channels in rat cerebellar Purkinje cells. J Physiol (Lond) 501:77-95.

Hensley SH, Yang X-L, Wu SM (1993) Identification of glutamate receptor subtypes mediating inputs to bipolar cells and ganglion cells in the tiger salamander retina. J Neurophysiol 69:2099-2107.

Jonas P, Sakmann B (1992) Glutamate receptor channels in isolated patches from CA1 and CA3 pyramidal cells of rat hippocampal slices. J Physiol (Lond) 455:143-171.

Jones MV, Westbrook GL (1996) The impact of receptor desensitization on fast synaptic transmission. Trends Neurosci 19:96-101.

Katz B, Miledi R (1969) Tetrodotoxin-resistant electric activity in presynaptic terminals. J Physiol (Lond) 203:459-487.

Lagnado L, Gomis A, Job C (1996) Continuous vesicle cycling in the synaptic terminal of retinal bipolar cells. Neuron 17:957-967.

Lester RAJ, Clements JD, Westbrook GL, Jahr CE (1990) Channel kinetics determine the time course of NMDA receptor-mediated synaptic currents. Nature 346:565-567.

Lukasiewicz PD, Werblin FS (1994) A novel GABA receptor modulates synaptic transmission from bipolar to ganglion and amacrine cells in the tiger salamander retina. J Neurosci 14:1213-1223.

Maguire G, Maple B, Lukasiewicz P, Werblin F (1989) $\gamma$-Aminobutyrate type B receptor modulation of L-type calcium channel current at bipolar cell terminals in the retina of the tiger salamander. Proc Natl Acad Sci USA 86:10144-10147.

Matsui K, Tachibana M (1997) Depolarization of a single bipolar cell activates both NMDA and non-NMDA receptors on ganglion cells in the newt retina. Jpn J Physiol 47[Suppl 2]:S159.

McBain C, Dingledine R (1992) Dual-component miniature excitatory synaptic currents in rat hippocampal CA3 pyramidal neurons. J Neurophysiol 68:16-27.

Mennerick S, Matthews G (1996) Ultrafast exocytosis elicited by calcium current in synaptic terminals of retinal bipolar neurons. Neuron $17: 1241-1249$.

Mennerick S, Zenisek D, Matthews G (1997) Static and dynamic membrane properties of large-terminal bipolar cells from goldfish retina: experimental test of a compartment model. J Neurophysiol 78:51-62.

Miller AM, Schwartz EA (1983) Evidence for the identification of syn- 
aptic transmitters released by photoreceptors of the toad retina. J Physiol (Lond) 334:325-349.

Mittman S, Taylor WR, Copenhagen DR (1990) Concomitant activation of two types of glutamate receptor mediates excitation of salamander retinal ganglion cells. J Physiol (Lond) 428:175-197.

Nowak L, Bregestovski P, Ascher P, Herbet A, Prochiantz A (1984) Magnesium gates glutamate-activated channels in mouse central neurones. Nature 307:462-465.

Patneau DK, Mayer ML (1990) Structure-activity relationships for amino acid transmitter candidates acting at $N$-methyl-D-aspartate and quisqualate receptors. J Neurosci 10:2385-2399.

Patneau DK, Vyklicky Jr L, Mayer ML (1993) Hippocampal neurons exhibit cyclothiazide-sensitive rapidly desensitizing responses to kainate. J Neurosci 13:3496-3509.

Sakaba T, Tachibana M, Matsui K, Minami N (1997) Two components of transmitter release in retinal bipolar cells: exocytosis and mobilization of synaptic vesicles. Neurosci Res 27:357-370.

Schwartz EA (1974) Responses of bipolar cells in the retina of the turtle. J Physiol (Lond) 236:211-224.

Schwartz EA (1986) Synaptic transmission in amphibian retinae during conditions unfavourable for calcium entry into presynaptic terminals. J Physiol (Lond) 376:411-428.

Silver RA, Traynelis SF, Cull-Candy SG (1992) Rapid-time-course miniature and evoked excitatory currents at cerebellar synapses in situ. Nature 355:163-166.

Silver RA, Colquhoun D, Cull-Candy SG, Edmonds B (1996) Deactivation and desensitization of non-NMDA receptors in patches and the time course of EPSCs in rat cerebellar granule cells. J Physiol (Lond) 493:167-173.

Slaughter MM, Miller RF (1983) Bipolar cells in the mudpuppy retina use an excitatory amino acid neurotransmitter. Nature 303:537-538.

Tachibana M, Okada T (1991) Release of endogenous excitatory amino acids from ON-type bipolar cells isolated from goldfish retina. J Neurosci 11:2199-2208.

Tachibana M, Okada T, Arimura T, Kobayashi K, Piccolino M (1993)
Dihydropyridine-sensitive calcium current mediates neurotransmitter release from bipolar cells of the goldfish retina. $\mathrm{J}$ Neurosci 13:2898-2909.

Taylor WR, Chen E, Copenhagen DR (1995) Characterization of spontaneous excitatory synaptic currents in salamander retinal ganglion cells. J Physiol (Lond) 486:207-221.

Toyoda J, Fujimoto M (1984) Application of transretinal current stimulation for the study of bipolar-amacrine transmission. J Gen Physiol 84:915-925.

Trussell LO, Thio LL, Zorumski CF, Fischbach GD (1988) Rapid desensitization of glutamate receptors in vertebrate central neurons. Proc Natl Acad Sci USA 85:4562-4566.

Trussell LO, Zhang S, Raman IM (1993) Desensitization of AMPA receptors upon multiquantal neurotransmitter release. Neuron 10:1185-1196.

von Gersdorff H, Matthews G (1994) Dynamics of synaptic vesicle fusion and membrane retrieval in synaptic terminals. Nature 367:735-739.

von Gersdorff H, Vardi E, Matthews G, Sterling P (1996) Evidence that vesicles on the synaptic ribbon of retinal bipolar neurons can be rapidly released. Neuron 16:1221-1227.

Werblin FS (1978) Transmission along and between rods in the tiger salamander retina. J Physiol (Lond) 280:449-470.

Werblin FS, Dowling JE (1969) Organization of the retina of the mudpuppy, Necturus maculosus. II. Intracellular recording. J Neurophysiol 32:339-355.

Wu SM (1987) Synaptic connections between neurons in living slices of the larval tiger salamander retina. J Neurosci Methods 20:139-149.

Wunk DF, Werblin FS (1979) Synaptic inputs to the ganglion cells in the tiger salamander retina. J Gen Physiol 73:265-286.

Yamada KA, Tang C-M (1993) Benzothiadiazides inhibit rapid glutamate receptor desensitization and enhance glutamatergic synaptic currents. J Neurosci 13:3904-3915.

Yu W, Miller RF (1995) Hyperosmotic activation of transmitter release from presynaptic terminals onto retinal ganglion cells. J Neurosci Methods 62:159-168. 